\title{
A review of the scholarly literature on CCPM: a focus on underpinning assumptions
}

\author{
Maryam Mirzaei* \\ Business Practice Pathway, \\ Unitec Institute of Technology, \\ Auckland, New Zealand \\ Email: mmirzaei@unitec.ac.nz \\ *Corresponding author
}

\author{
Victoria J. Mabin \\ Victoria Business School, \\ Victoria University of Wellington, \\ Wellington, New Zealand \\ Email: vicky.mabin@vuw.ac.nz
}

\begin{abstract}
Since critical chain project management (CCPM) was introduced, there have been many reports of its successful application, along with some claims of its shortcomings. However, there has been no attempt to reconcile the often-contradictory claims. To this end, we compiled and analysed a comprehensive database of CCPM scholarly publications. The literature analysis was complemented with text mining using NVivo and Leximancer software. We identify five assumptions CCPM makes about projects, leading to five characteristics that projects need to have for CCPM to apply fully and thus, provide the expected benefits. These characteristics are unity of purpose, fixed 'throughput', urgency, sequential workflow and a non-dedicated team. If projects have these or can be adapted, then they will suit CCPM. Through the process of assumption challenging, this research extends and enhances our understanding of CCPM and its core mechanisms.
\end{abstract}

Keywords: critical chain; theory of constraints; literature review; assumptions; critical chain project management; CCPM; TOC; text mining.

Reference to this paper should be made as follows: Mirzaei, M. and Mabin, V.J. (2018) 'A review of the scholarly literature on CCPM: a focus on underpinning assumptions', Int. J. Project Organisation and Management, Vol. 10, No. 3, pp.242-267.

Biographical notes: Maryam Mirzaei graduated as an Industrial Engineer from the Amir Kabir University, Tehran, Iran and completed her MPhil by research on Project Risk Management at the Faculty of Engineering, Peradeniya University, Sri Lanka and $\mathrm{PhD}$ at the Victoria Business School, Victoria University of Wellington, New Zealand. Her PhD thesis is titled 'Exploring applicability of theory of constraints to projects: critical chain project management and beyond'. In addition to her postgraduate research on project management, she worked for several years as Project Manager and the Project Management Office (PMO) Manager. She has worked on some of the largest construction projects in Sri Lanka, including post-tsunami reconstruction projects. She now teaches operations, supply chain and project management and constructed the TOC research database referred to in the paper. 
Victoria J. Mabin is a Professor of Management specialising in TOC and Decision Sciences. She has worked as an analyst consultant to business, government and industry on a wide range of strategic and operational problems. She is TOCICO certified, TOC Academic Jonah, Fellow of the Operational Research Society (UK), and ORSNZ Hans Daellenbach Award-winner. She has published widely, co-authoring The World of the Theory of Constraints, and TOC Thinking Processes in Theory of Constraints Handbook, led the TOC Research Database project, and served on the Board of Directors for TOCICO, and editorial boards for International Transactions in Operational Research, and Decision Sciences Journal of Innovative Education.

\section{Introduction}

It is now a quarter of a century since the first introduction of critical chain project management (CCPM) at the International Jonah Conference in 1990 (Bevilacqua et al., 2009; Goldratt, 1997). Since then, CCPM has been successfully applied to a wide variety of projects, as described in both practitioner and academic literatures (Newbold, 1998; Leach, 1999; Goldratt, 2008a; Paseuth, 2003; Realization Technologies, 2010). One application (Srinivasan et al., 2007) reported a large reduction in repair turnaround time of aircraft by implementing CCPM, winning the 2006 Franz Edelman Award for Achievement in Operations Research and the Management Sciences. CCPM has also been the subject of many scholarly discussions and has been described as being the direction for project management in the 21st century (Steyn, 2002; Deac and Vrincut, 2010) and a "genuinely original approach that develops motivational energy" [Morris, (2013), p.92]. From a practitioner perspective, the adoption of CCPM appears to be considerable: according to the most recent annual global survey of project management practitioners, $65 \%$ of project organisations have used CCPM and 37\% use it 'always' or 'often' [PMI, (20150, p.22]. The topic has also gained academic interest, as is evident by increasing publications in the academic literature.

However, there have been several criticisms of CCPM, centring on over-simplification (Herroelen and Leus, 2001), debates about buffer size calculation (Ashtiani et al., 2007; Jian Bing et al., 2008; Kuo et al., 2009) and a lack of applicability to a wide range of projects (McKay and Morton, 1998; Morris, 2013; Raz et al., 2003). This latter criticism of lack of applicability is particularly puzzling, because CCPM claims successful applications across a wide range of industries (Realization Technologies, 2010). So far, there has been no real attempt to reconcile these two opposing views. Perhaps, project managers in those reported successful applications have intuitively or via trial and error, chosen projects that suited CCPM, or they have tailored CCPM or modified aspects of their environment to accommodate CCPM application. Whichever is the case, they appear to have leveraged their success on the core advantages of CCPM. This prompts the questions: "What are the core advantages of CCPM? What do we need to know about CCPM in order to be able to leverage its core advantages?"

Goldratt (2009, p.336) argues "an application makes assumptions (sometimes hidden assumptions) about the environment and we should not expect the application to work in environments for which its assumptions are not valid." CCPM as an application relies on 
concepts, philosophy, assumptions and logic that form an ontology or model of reality, about projects and how they should be managed. We use the term underpinning to refer to this model of reality. These underpinnings may be explicit or implicit. This paper presents findings of a broader research (Mirzaei, 2016) that applied 'standing on the shoulders of giants' (SOSG) (TOCICO, 2011) to CCPM. The SOSG process requires thorough investigation of the giant's assumptions. The giant here is CCPM. This paper thus seeks to understand the CCPM solution exhaustively by examining its underpinning assumptions. This examination is based on an extensive literature analysis.

The CCPM literature presents different perceptions of CCPM: several scholars focus on $\mathrm{CC}$ scheduling and buffer allocation method as mere scheduling technique. This view does not require adherence to broader guidelines contained within CCPM and may overlook the impact of human behaviour on actual project performance (Huang et al., 2012). However, other scholars endorse CCPM as a systemic approach to project management with a distinct underpinning philosophy (Koskela et al., 2010; Leach, 2005; Lechler et al., 2005; Morris; 2013; Newbold and Lynch, 2014). In this view, CCPM applies to all aspects of a project beyond mere scheduling and time management. This raised another question: "Can CCPM scheduling techniques deliver intended benefits when applied without regard to the underpinning logic of CCPM as a systemic solution to project management?"

The structure of the paper is as follows. We first explain the methodology used for conducting this research. We then present findings: firstly, by offering an overview of CCPM applications to assess its versatility; secondly, by looking at the problems that formed the basis for CCPM development and how CCPM emerged as a solution to those problems. We then move deeper into re-examining the assumptions, concepts and terms used in CCPM. Finally, we conclude by presenting the practical and theoretical implications of this research.

\section{Methodology}

Scholars have called for a rethinking of existing concepts and assumptions in project management (Ahlemann et al., 2012; Koskela and Howell, 2002a, 2002b; Packendorff, 1995; Turner and Muller, 2003; Winter et al., 2006). This was strongly advocated by Hallgren (2012, p.812) who, after investigating how researchers in project management construct research questions, identified a "lack of assumption-challenging research" which, it was argued, "may hinder project research's development" particularly because in project management "many contributions tend to be based on long-lost principles." The present research responds to this by focusing on investigating CCPM's assumptions, some of which are found to be based on commonly-accepted concepts in project management, thus responding to the call for rethinking concepts in project management.

Pollack (2007) suggests examination of collective views to understand commonly accepted concepts and assumptions. Our research followed this advice by compiling and analysing a comprehensive database of CCPM scholarly publications, to identify tendencies, trends and the most common CCPM views on what a project is and how it should be managed. The strategy for developing the database of CCPM-related publications began with an extensive search of journal articles and conference proceedings using internet databases and search engines including ProQuest, Google Scholar, IEEE Xplore, WorldCat, ScienceDirect and Scopus. Key terms and phrases 
included 'critical chain', CCPM and the conjunction of 'project management' and 'theory of constraints'. Any publication that either debated or discussed elements of the critical chain, or described applications of the method, was included. In addition, we used citations to identify further entries, aiming to develop a comprehensive and inclusive database of as many scholarly CCPM publications as possible. Items were recorded in an endnote library and unrelated items were then eliminated after careful examination of references and abstracts. Through this process, 288 articles were identified; the resulting database is available at https://www.victoria.ac.nz/som/research/theory-of-constraints.

Note that books and the more clearly practitioner-based literature are not included in this database. Books on CCPM are generally not peer-reviewed and a listing is available elsewhere (Cox, 2016) for interested readers. The TOCICO website also offers video presentations with detailed descriptions of actual cases that used CCPM.

In order to analyse implicit assumptions, we undertook a qualitative analysis of the literature, augmented by text mining to obtain further insights regarding how words and their associated concepts were used. Text mining is typically defined as a process of extracting useful information from document collections through the identification and exploration of interesting patterns (Feldman and Sanger, 2007). We used a corpus of text generated from the 288 documents (pdf files) from the above database and employed both Leximancer and NVivo as each offers advantages in certain features and functionalities. Leximancer is a text mining software that analyses the content of collections of textual documents and presents it visually. The conceptual map generated in Leximancer provides an overview of the text, demonstrating the main concepts contained within the text and how they are related. Leximancer uses 'complex network theory' and 'machine learning' (Leximancer, 2010). Leximancer has successfully been used in similar research contexts for analysing text (e.g., Biesenthal and Wilden, 2014; Dann, 2010; Martin and Rice, 2007; Liesch et al., 2011; Scott and Smith, 2005; Smith and Humphreys, 2006).

NVivo was used for word-combination analysis, another important text-mining technique. For this purpose, the query function of NVivo was used to search for a target word and then the target word and its neighbouring text (five words before and after) were copied into a new file and were analysed. One limitation of text mining is that all publications are considered of equal merit. Accordingly, the text mining analyses using both these two software tools were mainly exploratory and helped us to orient our search and readings, develop expectations and test assumptions. Some visual representations along with interpretations drawn are presented in this paper. The guidance from such text mining complements the findings of the more traditional literature review based on direct reading of key sources, by providing a more comprehensive and data-driven exploration of the usage of terms in the CCPM scholarly literature.

\section{An overview of CCPM}

CCPM builds upon earlier methods within TOC, particularly drum buffer rope (DBR) (Goldratt and Fox, 1986). The development of DBR entailed learning from and challenging assumptions of flow line, Toyota production system and lean (Goldratt, 2009). Likewise, CCPM built upon CPM and PERT concepts and challenges assumptions of those methods. Both CCPM and DBR rely on buffer management as their core 
mechanism. Buffer management is built on queuing theory and the statistical law of aggregation (Hopp and Spearman, 1996) and uses patterns of information to stabilise a system. This mechanism echoes the thermostat model as described by Hofstede (1978). As a mechanism, buffer management also reflects the TOC doctrine 'think global, act local'. Deviations are not defined in isolation but in relation to their effect on the system; they are then treated individually, so as to act better collectively. Buffer management is also influenced by common cause variation, as explained by Deming (1986, pp.314-315). Deming (1986) emphasised the importance of differentiating variation by causes inherent in the system from other types of variations.

CCPM is defined as "the TOC solution for planning, scheduling and managing performance in a project environment" [Cox et al., (2012), p.37]. As will be explained later, the application of CCPM also requires eliminating multitasking and implementing new behaviours such as the relay runner work ethic and frequent reporting of work remaining. For further details on the CCPM implementation process and usage, refer to the TOCICO Dictionary [Cox et al., (2012), p.37] and Chapter 3 of the TOC Handbook (Budd, 2010). There are also a number of books that explain the application of CCPM (e.g., Leach, 2000; Kendall and Austin, 2012) in great depth.

Some extreme opinions on CCPM's merits have been expressed, which may be due to a lack of coherent and continued academic conversation on CCPM. In fact, 57\% of CCPM papers in our study were published in outlets that have only hosted CCPM discussions once. Another contributor to such extreme opinions is a dominance of theoretical debate, a reliance on mathematical simulations divorced from practice and a scarcity of case reports, in the CCPM literature. Ghaffari and Emsley (2015), for example, found that despite the need for more case studies on CCPM applications, case reporting papers still constitute a small segment (13\%) of the total publications on CCPM.

Nevertheless, several studies confirm that CCPM outperforms CPM and PERT (e.g., Pittman, 1994; Yang, 2007; Huang and Yang, 2009; Huang et al., 2012; Min and Shou-Rong, 2013). Successful applications of CCPM as it is presented in scholarly publications reveal a diverse range of projects: aircraft maintenance (Srinivasan et al., 2007), construction (Deac and Vrincut, 2010), production and manufacturing (Paseuth, 2003; Umble and Umble, 2000), software development (Reddy, 2009), aerospace combat systems development (Smith, 2012), production and distribution of fast-moving consumer goods (Viljoen and Steyn, 2007), pharmaceutical product development (Huang et al., 2013; Kania et al., 2002), public works (Kishira, 2006), high risk maintenance in oil refinery plants (Bevilacqua et al., 2009), e-learning projects (Abouzahra, 2011), biotechnology (Chang et al., 2010) and services (Yu and Chiu, 2007). In addition to the academic literature, one major CCPM commercial vendor, Realization Technologies (2010) provides a list of past projects revealing a diverse range of project types (Kendall, 2010). The reports are impressive in terms of both the significance of improvements and the diversity of project types.

A study of 140 industry-specific CCPM scholarly publications showed that the largest number of industry-specific published papers (45\%) discussed the application of CCPM to the construction industry, followed by manufacturing $(28 \%)$, software $(12 \%)$, research and new product development $(9 \%)$, service $(4 \%)$ and mining (2\%) (Mirzaei et al., 2014). While this distribution of application leans heavily towards construction and manufacturing, it is still diverse in nature. Such diversity, along with the numerous examples listed above, suggests that CCPM is a versatile approach. 
Such a diversity of successful applications suggests that the applicability of CCPM is not defined by industry or project size, or even by the level of uncertainty, as some have claimed (Morris, 2013; Raz et al., 2003). In fact, CCPM explicitly establishes itself as a generic solution to chronic problems within project management, which is discussed in the Section 4.

\section{CCPM as a solution to chronic problems in project management}

CCPM is often presented as a TOC solution to chronic problems in project management (e.g., Goldratt, 1997; Leach, 1999; Pittman, 1994; Walker, 2010). In the broader project management literature, CCPM is also seen as a method that, unlike other project management methods, was devised after "a thorough problem analysis rooted in empirical observation and theoretical interpretation" [Ahlemann et al., (2012), p.52]. Ahlemann et al. (2012) also claim that CCPM development resembles a design science approach. According to TOC, in every system, seemingly numerous and unrelated problems are in fact 'undesirable effects' that are caused by a few underlying root causes, the primary one being called the 'core constraint'. TOC solutions are devised to divert focus to the core constraint and to then exploit it as the leverage point. Therefore, CCPM development can be explained via a closer look at the problem analysis and solution design as presented in the CCPM literature; each of these is discussed as follows.

\subsection{Problem analysis}

The empirical observation was in the form of typical problems observed in projects, which were woven into the narrative in the novel Critical Chain (Goldratt, 1997). These typical problems in project management were said to be 'excessive activity duration', 'lack of positive variation', 'failure to pass on positive variation', 'delays caused by path merging', 'multitasking' and 'loss of focus'. Pittman (1994) and Walker (1998, 2010) demonstrated the widespread existence of each of those problems, based on extensive literature reviews. In addition to stating these problems, Walker (2010) explained their causes. In Figure 1, we provide a synthesis and summary of the work of both these authors, diagrammatically linking the problems with both their causes and their effects on the project.

The above problems are often attributed to the shortcomings of practices using traditional scheduling methods, PERT and CPM. In response to some of these problems, several scholars argued that practical problems were beyond scheduling solutions [Sculli and Wong, (1985), p.239] and even perhaps beyond systems thinking (Johnson, 2001). However, Pittman (1994) conducted extensive simulation analyses that clearly demonstrated the effect of assumptions made during planning on the execution process, when using CPM and PERT. Pittman (1994) concluded that many project problems (listed in Figure 1) are the result of wrong assumptions in these pre-existing scheduling methods. Goldratt (1997) argued that the inability to manage uncertainty was the core cause of project failure. Thereby, inability to manage uncertainty can be considered as a root cause for most of the problems discussed by Pittman (1994) and Walker (2010) in Figure 1. Pittman (1994) also demonstrated that such problems were resolvable by 
implementing a more realistic schedule and a systems approach that connects the plan and schedule with decision support required during execution.

Figure 1 Project management problems and their causes (see online version for colours)

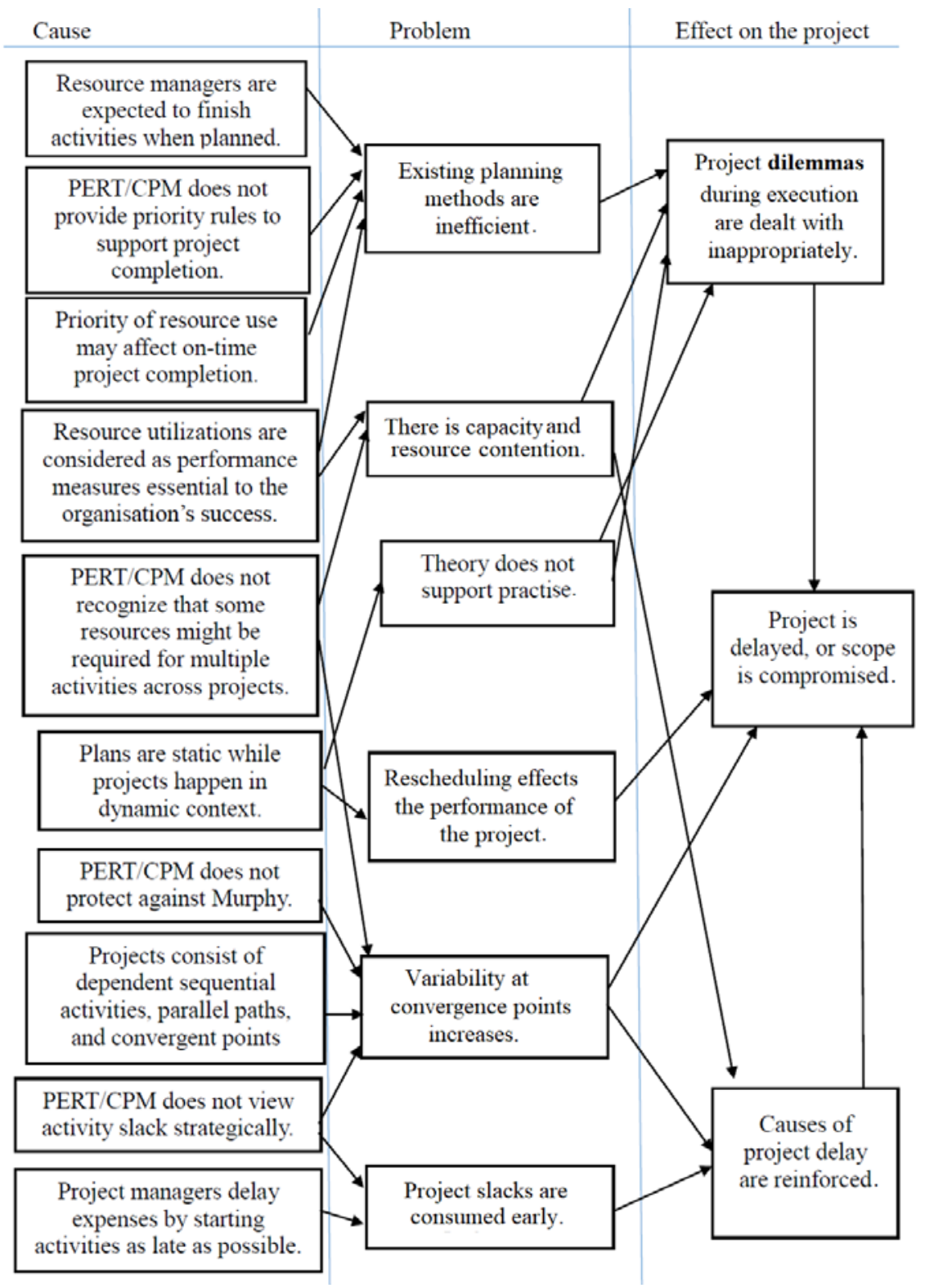

Source: Adapted and synthesised from Pittman (1994) and Walker (2010)

CCPM draws attention to human behaviour and the way plans are constructed and actually executed in the context of human interactions. One of the problems often discussed in the CCPM literature is the effect of a combination of such behaviours on project delays. The CCPM literature refers to several problems caused by overlooking 
commonly observed human behaviours. Such behaviours include: 'deliberate padding' by resource managers - padding their task estimates in order to avoid being late on commitments; 'Murphy's law' - if anything can go wrong it will; 'Parkinson's law' work extends to fill the time allowed; and 'student syndrome' - the type of procrastination students are prone to when they are assigned a project or are facing a test (Goldratt, 1997; Huang et al., 2012; Leach, 1999; Newbold, 1998). Lack of connection between planning and what actually happens in real-world execution results in a lack of decision support during execution. When deviations from the plan occur, various conflicts emerge between the interests of performance at the project level (project manager's responsibility) and better performance at a task level (resource manager's responsibility). Examples of such conflicts are shown in Table 1.

Table 1 Project management dilemmas

\begin{tabular}{lcc}
\hline $\begin{array}{l}\text { Action leads to better } \\
\text { performance at a task level }\end{array}$ & $\begin{array}{c}\text { Action leads to better } \\
\text { performance at the project level }\end{array}$ & References \\
\hline $\begin{array}{l}\text { Include contingency in } \\
\text { individual task estimates }\end{array}$ & $\begin{array}{c}\text { Do not include contingency in } \\
\text { individual task estimates } \\
\text { Accept new tasks }\end{array}$ & Leach (2005, p.80) \\
$\begin{array}{l}\text { Complete committed work } \\
\text { Do not turn in work early } \\
\text { Formally change the critical } \\
\text { path }\end{array}$ & $\begin{array}{c}\text { Turn work in early } \\
\text { Dot formally change the } \\
\text { critical path }\end{array}$ & Leach (2005, p.86) \\
$\begin{array}{l}\text { cost world } \\
\text { Start work early (push }\end{array}$ & $\begin{array}{c}\text { Manage according to } \\
\text { throughput world }\end{array}$ & Goldratt (1997, p.211) \\
approach) & Start work late (pull approach) & (2005, p.59), Leach \\
& & $\begin{array}{c}\text { Millhiser and Szmerekovsky } \\
(2012), \text { Viljoen and Steyn }\end{array}$ \\
\hline
\end{tabular}

Goldratt (1997, p.85) challenged the assumption that good performance in individual parts of a system leads to overall better performance. Likewise, in a project, instead of focusing on each and every activity, the focus should be on the most important chain of dependent activities [Goldratt, (1990), p.185]. CCPM, like other TOC solutions, was devised to divert focus on the core constraint and exploit it as the leverage point.

A well-known concept, a constraint is usually defined as "something that limits or restricts someone's actions or behaviour" (Constraint, n.d.). Outside of TOC, a constraint is usually viewed as something that should preferably be eliminated. However, TOC takes a different approach and views constraints as the 'opportunity for improvement' (Gupta et al., 2010). In TOC literature, a constraint is "the factor that, if the organisation were able to increase it, more fully exploit it, or more effectively subordinate to it, would result in achieving more of the goal" [Cox et al., (2012), p.28]. TOC literature not only perceives constraints positively, but also, influenced by the Pareto principle, suggests that a system typically has few constraints that limit the system performance relative to its goal (Blackstone et al., 1997). Accordingly, these few constraints are a good place to control or influence the system. The next section discusses how CCPM was devised as a means to exploit the core constraints in a project environment. 


\subsection{Solution design}

According to TOC, in every system, seemingly numerous and unrelated problems are in fact 'undesirable effects' that are caused by a few underlying root causes, the primary one being called the 'core constraint'. Goldratt (2010, p.3) argues that "focusing on everything is synonymous with not focusing on anything." TOC solutions are devised to divert focus to the core constraint and to then exploit it as the leverage point. This process of improving a system by identifying and focusing on the constraint(s) as the leverage point has been spelled out as the 5FS. Thus, CCPM could be interpreted as having been based on 5FS (implicitly even if not literally). Many authors refer to 5FS processes or individual steps within the processes in their justifications for CCPM prescriptive processes. Leach (1999) and Steyn (2001) run through the full set, focusing on CCPM application to a single project, while others referred to particular steps within the process. Table 2 draws these contributions together and summarises CCPM solutions for both single projects and multi-project environments corresponding to steps of the 5FS. These steps are then discussed.

Table 2 The five focusing steps and CCPM processes

\begin{tabular}{|c|c|c|c|}
\hline \multicolumn{2}{|c|}{$\begin{array}{l}\text { The five focusing steps } \\
\text { [Goldratt, (1988), p 453] }\end{array}$} & Single project & Multi-project context \\
\hline \multicolumn{2}{|c|}{$\begin{array}{l}\text { Prerequisite } 1 \text { - identify } \\
\text { the system and its } \\
\text { purpose }\end{array}$} & $\begin{array}{l}\text { A project - a temporary } \\
\text { undertaking (Leach, } \\
\text { 1999; Steyn, 2001) }\end{array}$ & $\begin{array}{l}\text { Collection of projects (Deac and } \\
\text { Vrincut, 2010; Globerson, 2000; } \\
\text { Goldratt, 2008b; Lechler et al., 2005) }\end{array}$ \\
\hline \multicolumn{2}{|c|}{$\begin{array}{l}\text { Prerequisite } 2- \\
\text { determine the system's } \\
\text { measures }\end{array}$} & $\begin{array}{l}\text { Duration (Leach, 1999; } \\
\quad \text { Steyn, 2001) }\end{array}$ & $\begin{array}{l}\text { Profit (throughput) (Deac and Vrincut, } \\
\text { 2010; Globerson, 2000; Goldratt, } \\
\text { 2008b; Lechler et al., 2005) }\end{array}$ \\
\hline 1 & $\begin{array}{l}\text { Identify the system's } \\
\text { constraint }\end{array}$ & $\begin{array}{l}\text { Longest chain of activity } \\
\text { [Goldratt, 1997; Leach, } \\
\quad \text { (2005), p.106] }\end{array}$ & $\begin{array}{l}\text { Bottleneck resource or virtual drum } \\
\text { (Budd, 2010; Cohen et al., 2004; } \\
\text { Goldratt, 2008b; Herroelen and Leus, } \\
\text { 2001; Huang et al., 2012; Leach, 2005; } \\
\text { Newbold, 1998) }\end{array}$ \\
\hline 2 & $\begin{array}{l}\text { Decide how to } \\
\text { exploit the system's } \\
\text { constraint }\end{array}$ & $\begin{array}{l}\text { Remove the individual } \\
\text { buffers (Goldratt, 1997, } \\
\text { Chapter 13) } \\
\text { Adopt necessity-based } \\
\text { logic (Realization } \\
\text { Technologies, 2010) }\end{array}$ & $\begin{array}{l}\text { No idle time for bottleneck resource or } \\
\text { virtual drum (Budd, 2010; Cohen } \\
\text { et al., 2004; Herroelen and Leus, 2001; } \\
\text { Goldratt, 2008b; Huang et al., 2012; } \\
\text { Leach, 2005; Newbold, 1998) }\end{array}$ \\
\hline \multirow[t]{2}{*}{3} & $\begin{array}{l}\text { Subordinate } \\
\text { everything else to } \\
\text { the above decision }\end{array}$ & $\begin{array}{c}\text { Add } \\
\text { project/feeding/resource } \\
\text { buffer [Cox et al., (2012), } \\
\text { p.76; Leach, 1999] }\end{array}$ & $\begin{array}{l}\text { Add capacity buffer (Budd, 2010; } \\
\text { Cohen et al., 2004; Herroelen and } \\
\text { Leus, 2001; Huang et al., 2012; Leach, } \\
\text { 2005; Newbold, 1998) }\end{array}$ \\
\hline & & & $\begin{array}{l}\text { Stagger the start date for projects } \\
\text { according to the bottleneck (Budd, } \\
\text { 2010; Cohen et al., 2004; Deac and } \\
\text { Vrincut, 2010; Goldratt, 2008b) }\end{array}$ \\
\hline 4 & $\begin{array}{l}\text { Elevate the system's } \\
\text { constraint }\end{array}$ & \multicolumn{2}{|c|}{$\begin{array}{c}\text { Add capacity (Steyn, 2001) if desired (e.g., overtime, extra } \\
\text { resources...) }\end{array}$} \\
\hline 5 & Repeat & $\begin{array}{l}\text { Not applicable to a single } \\
\text { project }\end{array}$ & $\begin{array}{l}\text { Modify buffer size and task time } \\
\text { estimates based on learnings from } \\
\text { recent projects (Mirzaei, 2016) }\end{array}$ \\
\hline
\end{tabular}


As indicated in Table 2, for a single project the measure of performance is assumed to be the duration of the project. CCPM repeatedly justifies this assumption by highlighting the temporary nature of projects (Yang, 2007). Pittman (1994, p.33) rationalises this by highlighting a difference between projects and non-projects, in that projects "only create revenues after completion". Leach (2005, p.106) also discusses some of the effects of the schedule on project cost and scope. Steyn (2002) counts three reasons for this emphasis on fast delivery: obtaining positive cash flow faster, contingency cost of delay and preventing changes to stakeholders' needs. The CCPM literature assumes achieving other project success factors such as quality is part of completing project tasks. For example, Leach (2005, p.106) argues that we cannot produce more of the goal (e.g., more outputs or higher value for the same output) in the same project and therefore the only way to improve performance is to deliver the deliverable faster. This argument implies we cannot or do not want to have a deliverable with better quality or more/higher specifications and that changes in the future are not desirable. This emphasis on time to deliver a fixed value in projects is not unique to CCPM; however, CCPM literature has made it explicit. Morris (2013, p.264) in his book Reconstructing Project Management states: "Time is the most potent resource in projects. The way we engineer value into it is one of the most significant acts that a project management team can perform. It is what Goldratt was aiming for with critical chain project management."

Newbold (2008, p.9) argues that if fast delivery is not your concern, CCPM "is probably not for you." CCPM's emphasis on duration implies a perceived urgency (requiring swift action) of projects. This is supported by the findings from text mining discussed later, where 'time' was the word used most frequently after 'project' and 'management' in the CCPM body of scholarly texts. This notion of urgency resembles Schmenner and Swink's (1998) theory of swift, even flow in operations management that attributes speed to productivity.

Successful application of CCPM has been repeatedly associated with a notion of fast delivery. Numerous case studies indicate faster delivery as their prime achievement (Abouzahra, 2011; Bacharach and Techi, 2013; Bevilacqua et al., 2009; Chang et al., 2010; Deac and Vrincut, 2010; Groves et al., 2000; Huang et al., 2013; Kania et al., 2002; Smith, 2012; Srinivasan et al., 2007; Stretton, 2007; Umble and Umble, 2000; Viljoen and Steyn, 2007; Yu and Chiu, 2007). In addition to academic literature, Realization Technologies' (2010) list of projects that implemented CCPM presents a diverse range of project types, all of which considered time reduction as their top gain from using CCPM.

The core constraint in a single project is a chain of dependent activities, where dependency is based on both precedence and resource availability. This indicates that at the project level, CCPM, like CPM and PERT, relies on systems and graph theory and portrays a project as a network of dependent activities. Accordingly, it assumes duration of the project is defined by the longest chain of dependent activities. However, unlike $\mathrm{CPM} / \mathrm{PERT}$, CCPM explicitly recognises that project duration is determined by the interaction between activity duration, precedence relations, resource requirement and resource availability, not simply the sum of activity durations of precedence relationships as in a critical path (Herroelen and Leus, 2001; Herroelen et al., 2002; Raz et al., 2003). CCPM therefore defines the system constraint to be the longest 'chain' of activities taking into account resource dependencies, termed the critical chain [Goldratt, 1997; Leach, (2005), p.106]. 
Since the critical chain is the core constraint and the objective is to shorten the project's duration, CCPM has devised two strategies to exploit the constraint, as follows. Firstly, CCPM encourages adopting necessity-based logic and rigorously challenging traditional assumptions about precedence relationships, resulting in more aggressive schedules, such as the schedule that resulted in habitat for humanity establishing a new world record for house building (Parr, 2000). The second strategy to shorten the critical chain is based on two commonly known concepts: common-cause variation and the statistical law of aggregation. Goldratt (1997, Chapter 13) argues that estimated durations are inflated in several layers of management to prevent delay caused by common-cause-variation phenomena: what happens in reality will usually be slightly longer or shorter than what appears in the schedule. This concept was highlighted by Deming (1986, pp.314-315), who argued that such variation is inherent in the system. Moreover, Leach (1999) explains that according to the statistical law of aggregation, a chain of dependent activities can be protected to the same level of probability using a shared buffer, with much less total safety time than when each individual activity is protected. Therefore, using these notions, the critical chain can be shortened by, firstly, removing individual task buffers by replacing inflated individual task times with $50 \%$ probable durations; and secondly, replacing these individual task buffers with a smaller aggregated buffer, at the end of the project.

The subordination process in Table 2 centres on buffer management, as the core of the execution process in CCPM. Buffers are time cushions that are employed to manage the impact of variation and uncertainty in projects and prevent non-critical activities from delaying critical activities (Goldratt, 1997; Leach, 1999; Newbold, 1998). CCPM does not recommend milestones or start and finish dates for individual tasks, unlike CPM and PERT (Deac and Vrincut, 2010; Lechler et al., 2005; Rand, 2000). Instead, in CCMP, each activity on the critical chain starts as soon as its precedent activity is finished, irrespective of the date. Buffers are placed prior to the intersection of non-critical chain paths and the critical chain and at the end of the project. A graph can be created to show the consumption of buffer as the project progresses and if the project buffer is being consumed at a faster rate than the project is being completed, then actions are taken to bring the project back on track. Accordingly, deviations from the predefined schedule are not treated at individual task level, but are acted upon collectively via buffer management (Horman and Thomas, 2005; Yeo and Ning, 2002, 2006). CCPM in effect uses buffer management as a decision support mechanism during execution to divert project managers' attention from numerous tasks and deadlines to a few important tasks that influence the final project completion dates.

Finally, elevating a system usually means increasing its capacity by means such as adding employees, new software or machines. However, CCPM literature often omits to discuss these steps. This may be because, since a project is a one-time undertaking, ongoing improvement is not considered to be relevant. Instead, the emphasis in CCPM literature has been on developing a 'stable schedule' (Hazır et al., 2010; Herroelen and Leus, 2004; Herroelen et al., 2002; Leus, 2004; Van De Vonder et al., 2005) that stays the same throughout the project. Goldratt (1990) argued that a realistic schedule should not be vulnerable to a normal level of disruption.

In a multi-project context, the measure of performance is the throughput. Throughput is a fundamental measure in TOC literature and is defined as the rate at which the system generates money through sales [Goldratt and Fox, (1986), p.29]. The core constraint in a multi-project environment is a resource that creates a bottleneck. The bottleneck 
resource, being the most constrained resource, determines the capacity of the whole organisation. This is similar to the simple bottleneck in TOC for production. Cooper et al. (2005) raise the issue of addressing resource constraints as the most important contribution of project portfolio management. It has been also been referred to as the most challenging aspect (Luong and Ario, 2007). The issue with scarce resources is not limited to projects and portfolios, but it has also been an important organisational performance indicator (Seashore and Yuchtman, 1967).

To exploit the constraints in a multi-project environment, CCPM prioritises projects to ensure most efficient use of scarce resources. CCPM offers a centralised prioritisation to eliminate inefficient use of resources and 'bad multitasking' and ensure no idle time for the most constrained resource. Prioritisation also facilitates the subordination process. Critical chain activities are prioritised over non-critical chain activities and activities in projects with higher buffer consumption are prioritised over activities in projects with lower project buffer consumption (Leach, 1999). Another important subordination is to stagger the start date for projects according to the availability of the bottleneck resource; in other words preventing the organisation from accepting new projects when the constraint is already used to full capacity (Budd, 2010; Cohen et al., 2004; Deac and Vrincut, 2010).

The final two steps of the 5FS are generally associated with adding more resources and making strategic decisions that elevate the system's capacity. Recent case study research in a multi-project environment found that learning occurs from one project to another project. Effective use of this learning helps the project team to improve their estimation of task times and buffer sizing across projects. This includes learning from the estimator's attitude (some people are optimists, others are pessimists) and the level of uncertainty of various tasks collectively [Mirzaei, (2016), p.120].

The CCPM multi-project prioritisation method can also be viewed as a portfolio selection and management method that aims at increasing throughput and is focused on allocation of resources. Chang et al. (2010) compare CCPM to some popular portfolio selection models such as present value of total revenues (PVTR) and present value of profit (PVP) and demonstrate the superiority of CCPM. Perhaps, the most distinct difference between the CCPM multi-project method and alternative portfolio selection methods is that it does not end with a plan; rather, it is execution-oriented. Projects are not chosen individually and ranked by their return on investment (ROI) or net present value (NPV), but collectively with the focus of optimal allocation of constraint resources in order to attain maximum throughput. Projects are scheduled according to shared bottleneck resources, which are referred to as 'drum' (Chang et al., 2010). This synchronised approach to multi-projects has been well supported in the broader project and portfolio management literature. Platje et al. (1994), for example, advocate the shift towards synchronised management of a whole collection of projects as a unit and linking the set of projects to a business strategy.

CCPM connects planning and execution together and both the scheduling and prioritisation techniques are closely interconnected with mechanisms advocated by TOC, such as buffer management, throughput accounting and cause and effect logic. CCPM literature is not only built upon the broader TOC body of knowledge but is also married with a list of project-specific recommendations that are beyond scheduling. CCPM literature also includes other aspects of project management, such as procurement management (Budd, 2010; Yeo and Ning, 2002); project reporting (Budd, 2010); cost 
management (Bevilacqua et al., 2009; Budd, 2010; Luong and Ohsato, 2008); project reporting (which emphasises communication management) (Budd, 2010); and risk (Bevilacqua et al., 2009; Leach, 2003; Luong and Ohsato, 2008; Steyn, 2002; Yeo and Ning, 2002). CCPM is also credited with reinforcing motivational energy among team members [Ishibashi et al., 2008; Kishira, 2006; Morris, (2013), p.92]. Leach (2005) presents CCPM as a full toolkit alongside TOC thinking processes. Newbold and Lynch (2014) also introduce a set of 'critical chain values' as a lens through which project managers can see and manage their projects.

So far, we have explained the argument in the CCPM literature that indicates how CCPM was devised as a solution to the core issue in projects: inability to manage uncertainty. CCPM solutions for both single and multiple project contexts focus mainly on scheduling tasks and resources and managing the execution via buffer management. Moreover, while the concept of a buffer can have different forms (time buffer, resource buffer, or even scope buffer), time buffer is the predominant type of buffer used in the CCPM literature. This seems to be a strategic emphasis on a core constraint, rather than a lack of appreciation of other aspects of project management.

However, the question remains: "How did CCPM arrive at this very specific definition of the core constraint for all projects? What does it assume to exist in project environments?" It seems there are still many assumptions left unstated. Our contention is that if we expose these hidden assumptions we may be able to better understand why CCPM is effective in some situations and not in others. To do this, we delve further into CCPM's assumptions.

\section{What CCPM assumes to exist in project environments}

This section explores how CCPM has arrived at its particular definition of the core constraint. This investigation looks at three key concepts used in the definition of the core constraint according to TOC: the core constraint prevents the system from achieving more of its goal. We first discuss the perception of a project as a system in CCPM literature and then move to discussing the project goal in a project environment. Lastly, we move on to the process of achieving the goal and how this process is envisioned in the CCPM literature

\subsection{The system}

TOC assumes the existence of a goal-oriented system and the clear definition of a system owner whose interest will set the goal for the system. CCPM suggests that the system owner has to set priorities for the good of the overall system, which again assumes there is one system and its owner can be clearly identified. However, a project could be part of multiple systems. When multiple systems interact, throughput and the constraint can be interpreted differently based on how we define the system. This does not mean CCPM cannot be applied to projects that involve multiple organisations. However, it does assume unity of purpose, in order to prevent counterproductive activities and in turn produce mutual benefits to all parties involved. Some types of contractual arrangements can facilitate achieving such unity of purpose. For example, various types of relationship contracting, partnering or alliancing (Rahman and Kumaraswamy, 2004; Heptinstall and Bolton, 2016) are developed specifically to align project parties. While outside CCPM 
this has been discussed as a desirable feature, we argue unity of purpose is a key prerequisite to CCPM implementation and is essential for its successful application, particularly to convince people who work on non-critical projects/tasks to subordinate their effort to critical projects/tasks.

\subsection{The goal}

As discussed earlier, CCPM literature implies that the goal of a project is to deliver a project as fast as possible while meeting an agreed scope and budget (Walker, 2010). CCPM recommends that the project plan is formulated using necessity-based logic, which implies that the scope of a project is decided prior to project initiation. This in turn suggests that in CCPM, unlike agile methods, scope is not something that will be figured out after the project has started. According to Walker (2010), the scope of a project should include only tasks that are necessary for achieving the goal, in other words CCPM seeks to deliver a 'minimum viable' solution. 'Minimum viable product', according to CCPM, is what a project as a whole delivers. This is the very reason project throughput, according to CCPM literature, is considered to be zero until completion. The focus in CCPM, therefore, is on how to deliver this fixed-scope project faster or more efficiently. This is in contrast to the minimum viable product used in agile methods; for example in Scrum, a minimum viable product is a much smaller unit - several of which can be delivered in a sprint. The focus in agile, therefore, is on what to deliver first in order to maximise the deliverable over the course of the project.

CCPM is intended to prevent deviations from a project's predefined scope. Coman and Ronen (2010) demonstrated that emphasis on fast delivery and freezing and stabilising the specifications prevents scope creep, implying that it is not considered desirable to allow scope to increase.

The analysis based on text mining shows very clearly that this is a commonly held view in the wider CCPM literature. The body of text generated from the occurrence of the word 'scope' and five words before and after was examined using NVivo and the word cloud generated using this body of text is presented in Figure 2. This shows that 'creep' is the word most frequently used close to 'scope' in CCPM literature.

Figure 2 Word cloud constructed using text in the same proximity as 'scope' extracted using NVivo

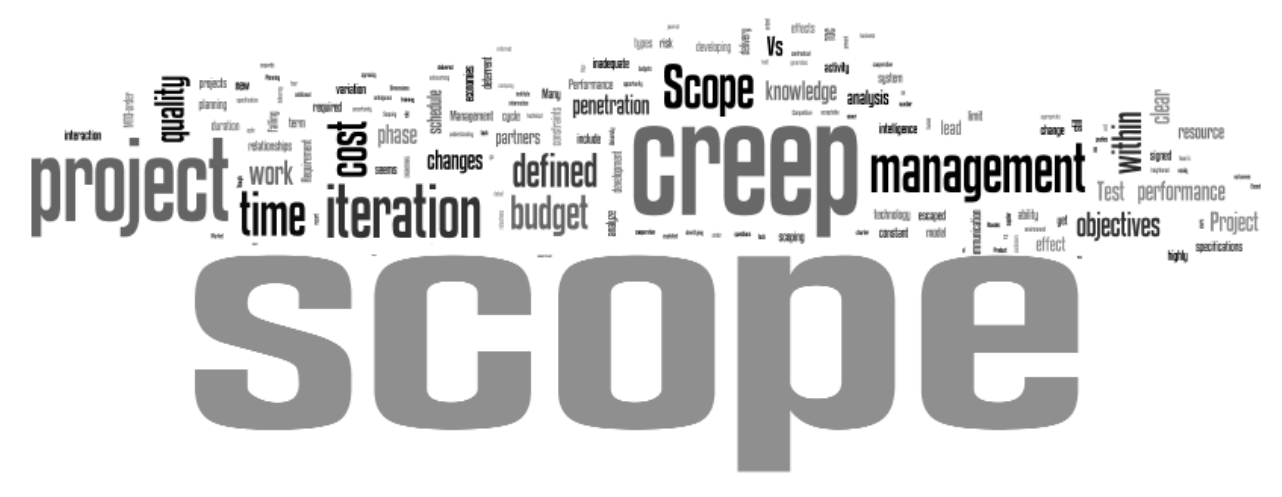


CCPM's emphasis on limiting project overruns is further encouraged through the '25:25 rule' (Goldratt, 2008b; Ronen et al., 2012) which encourages organisations to freeze $25 \%$ of their projects, to allow the remaining projects to be finished faster and to cut the scope of these remaining projects by $25 \%$, removing unnecessary 'bells and whistles' that may have been in the initial project specifications and are really not essential yet add time and cost to the projects. These two ways of reducing the promised deliverables are said to speed up completion so that even the frozen projects - if chosen to be reinstated - can be completed faster than if all were allowed to proceed concurrently.

\subsection{How to achieve the goal?}

Turning now to how the project is to be achieved, CCPM approaches the task by addressing what it perceives as the main barrier to completing a project on time, namely uncertainty. According to Goldratt (1997), inability to manage uncertainty and variability is the core cause of the majority of project problems. He accepted variability and uncertainty as 'facts of life' and suggested buffer management to manage them, as previously discussed. In contrast, proponents of agile methods claim that we cannot know in advance what will be needed in a project - i.e., there is uncertainty in scope.

Figure 3 Concept map generated by Leximancer software from the corpus of text in CCPM scholarly publications within five sentences of the word 'uncertainty' (see online version for colours)

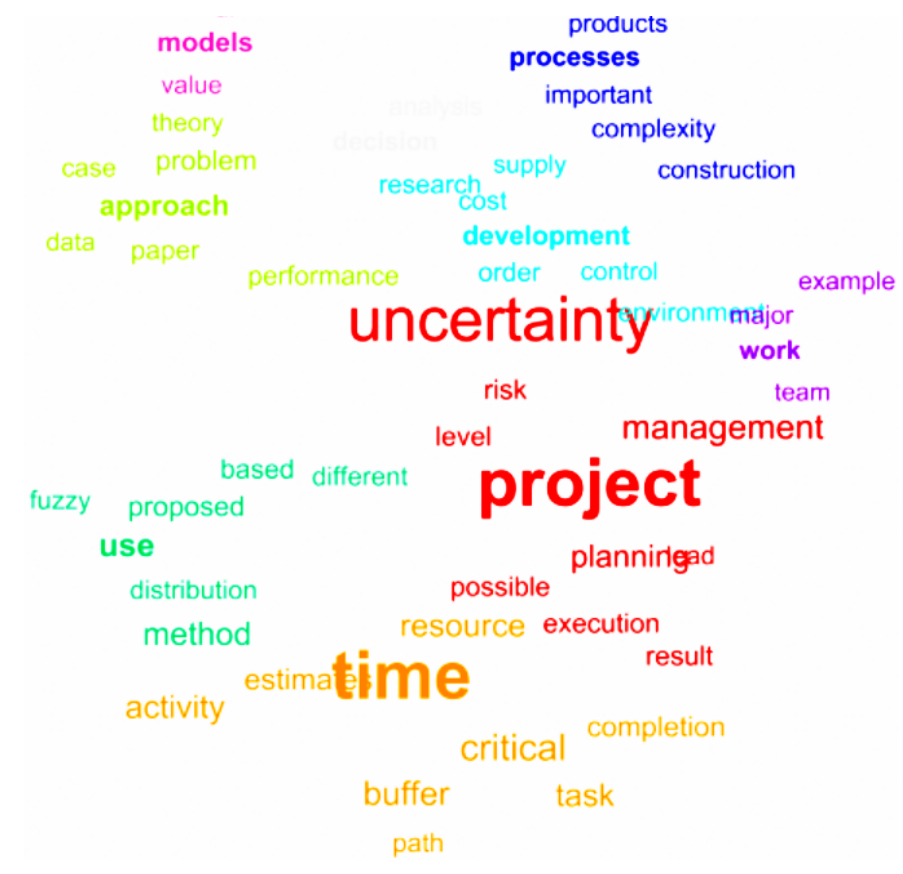

Accordingly, we analysed how 'uncertainty' has been interpreted in CCPM scholarly texts, to determine how it is discussed in CCPM literature. Figure 3 shows the thematic map of the corpus of text that was generated by selecting text referring to the concepts of uncertainty, along with text within the neighbouring five sentences in both directions, 
using Leximancer. The text indicates high use of concepts related to time and planning in close proximity to the word 'uncertainty'. The thematic map suggests uncertainty is most often discussed in relation to schedule, rather than scope. Both thematic analyses of 'uncertainty' and the word-combination analysis of the word 'scope' show that these concepts are not often discussed together. This implies that uncertainty is perceived in CCPM as being more related to the process of achieving the goal, rather than to the goal itself; in other words how to deliver the goal rather than what to deliver. Given, CCPM literature offers time-based buffer management as a solution to uncertainty, it is evident that CCPM uses 'uncertainty' to refer to variations in task duration.

Buffer management emphasises ongoing scanning of progress as measured buffer consumption in order to bring the project back on track when buffer is being consumed too fast. This is equivalent to a 'negative feedback' process in the thermostat model as explained by Hofstede (1978) or in a system dynamics model (Forrester, 1961; Senge, 2006). However, Koskela and Howell (2002b) argue that assuming intervention will cause change when required may not hold true in all projects. This raises the question "What is CCPM/TOC's stand on managing complex systems in a human context?"

The response to this question has been a strong theme running through TOC from the beginning. Goldratt's (1984) The Goal: Excellence in Manufacturing was primarily focused on directing human behaviour into alignment with the system goal. Deming (1986, p.110) also placed great emphasis on human behaviour aspects, linking them to the systems created by management. Goldratt (1990, p.26) argued, "Tell me how you measure me and I will tell you how I will behave." Two decades later, in response to debates on complexity of human behaviour, Goldratt (2008b) restated two major TOC assumptions: there is inherent simplicity in systems and people are good. In TOC, human behaviour is seen to be intimately associated with the design of the system in which humans operate. Accordingly, TOC advocates designing a system in such a way that motivates and capitalises on human behaviour. This in turn points to a predominant assumption of TOC: humans will behave logically and such behaviours are predictable.

Goldratt (1997) turned to using the metaphor of a 'relay race' or 'relay runner' to achieve on-time completion of a project (Newbold, 1998). TOCICO Dictionary [Cox et al., (2012), p.105] defines relay runner work ethic as follows: "the process of applying a focused effort (i.e., no multitasking) to complete a task and handing it off immediately to a resource waiting and prepared to take the hand-off." The relay runner mindset is highly suited to situations where speed is of the essence, preventing projects being delayed at handover times. It does so by encouraging desired behaviours such as reporting early completion of activities, timely and smooth handoffs, a focus on critical activities by eliminating multitasking and obviating the need for milestones. This view is also consistent with the concept of flow and its connection to improved productivity (Goldratt, 2008b; Schmenner and Swink, 1998). The smooth handoff is accomplished by frequently (daily) asking the resource working on the current $\mathrm{CC}$ task: how much time before the current task (on CC) is completed? This allows the next resource working on the $\mathrm{CC}$ the opportunity to adjust to maintain continuity between departments. CCPM advocates claim that this overcomes problems caused by commonly observed human behaviours in projects, such as Parkinson's law where the time spent on tasks is defined by the due date rather than the time it actually needs and the 'student syndrome' where procrastination causes early buffer consumption without corresponding progress on the project task. 
We also looked into usage of the word 'resource'. The word frequency analysis of text in the CCPM literature showed that the most popular words used in combination with 'resource(s)', besides 'project', were 'constraint', 'scheduling', 'allocation' and 'critical'. Another interesting observation was made when looking at usage of terms 'contention' and 'conflicts' in close proximity to 'human resource'. We extracted texts that had a combination of 'human resource' and 'conflicts' or 'contention' and analysed the context in which they were used. The results suggested that such problems are often followed by scheduling solutions. This again reinforces the perceived importance of the project schedule as the primary coordination mechanism in CCPM to manage human resources in a project context.

Regardless of how resources interact, for constructing the critical chain, existence of a logical sequence of activities or events is essential. Pittman (1994, p.7) explicitly states: "No event can be repeated and no 'looping back' to predecessors is permitted." The 'relay runner' metaphor also assumes that projects consist of a sequence of distinct unidirectional processes. In this view each actor completes a task and hands over to the next actor. However, interaction between human resources when completing a task together is not always sequential. Thompson (1967, pp.54-65), for example, classifies processes into 'independent', 'sequential' and 'reciprocal' and suggests that interdependency increases from 'independent' to 'sequential' and to 'reciprocal'. Moreover, the process itself may not be unidirectional. Interestingly, there are examples where CCPM has been successfully applied to projects with iterative loops or with reciprocal dependencies (Mirzaei, 2016). This was made possible by either allowing reciprocal iteration at the task level [Figure 4(a)] or allowing iterations at a higher level than the project [Figure 4(b)]; in both cases the critical chain itself does not contain any loops.

Figure 4 (a) Reciprocal iteration within tasks and critical chain at the project level (b) Critical chain at sub-project level and iteration at higher level (see online version for colours)

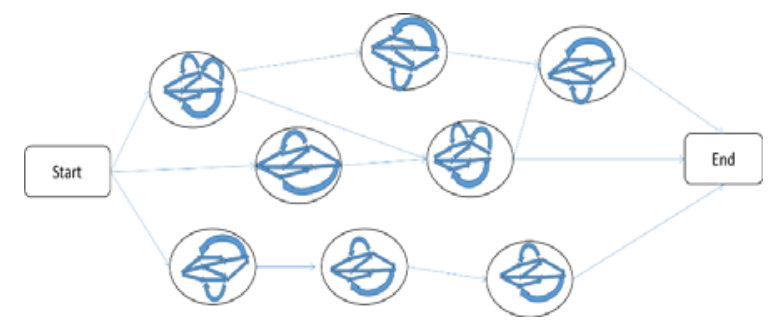

(a)

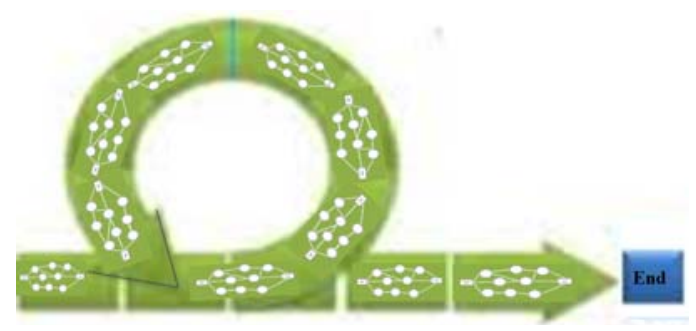

(b)

Source: Mirzaei (2016) 
Both these approaches are consistent with the CCPM literature. This is because there is no general rule to say to what level a major task should be broken down. For example, Srinivasan et al. (2007) refer to tasks with hourly measures, which indicates fine granularity, whilst Newbold and Lynch (2014, p.23) in their book The Project Manifesto: Transforming Your Life and Work with Critical Chain Values state: "We created a high level map in order to get a 30,000-foot picture of the project."

A further factor predicating the use of a schedule as the core coordination mechanism is that projects always use a non-dedicated team whose members enter and leave the project sequentially and are best coordinated via a schedule. A classic example would be tradespeople entering and leaving a building site, who perform specialised tasks that must often be undertaken in a strict sequence. If the site is not ready for their task, they will leave and return later or they will have to wait idle until their task starts. To prevent such costly incidents, project managers add buffer within individual tasks, which delays the project. It can be argued that avoiding deadlines and milestones in the critical chain and encouraging the right behaviours via the relay runner mindset, combines mutual adjustment with the traditional view of a schedule. However, in situations where team members substitute for each other where needed, a dedicated team (where all project team members work together throughout the project, e.g., Scrum) can reduce impact of variability in the project schedule. In such context the process becomes reciprocal and coordination is mostly facilitated via mutual adjustment (Mirzaei and Mabin, 2015).

Thompson (1967) argues that as interdependency increases, the demand for coordination changes. Low levels of interdependency can be managed by planning and scheduling, while higher levels of interdependency require various mutual adjustment mechanisms. It is argued here that buffer management and relay runner ethics are forms of mutual adjustment. We contend that it is the combination of both these mechanisms that provides a further clue to tailoring CCPM to different contexts.

The above discussion extends our understanding of CCPM assumptions. Table 3 summarises the above assumptions in relation to steps in the process of 5FS discussed earlier.

Table 3 Summary of CCPM assumptions

\begin{tabular}{|c|c|}
\hline Five focusing steps (5FS) & CCPM assumptions highlighted in this paper \\
\hline $\begin{array}{l}\text { Prerequisite } 1 . \text { Define the } \\
\text { system and its goal }\end{array}$ & $\begin{array}{l}\text { Project is one system and there is unity of purpose. Human } \\
\text { behaviour follows cause-and-effect logic. If a system is well } \\
\text { designed, complexity due to human behaviour can be managed. }\end{array}$ \\
\hline $\begin{array}{l}\text { Prerequisite } 2 \text {. Define the } \\
\text { measurements that align } \\
\text { the system to that } \\
\text { purpose }\end{array}$ & $\begin{array}{l}\text { Project delivers a minimum viable product that generates a fixed } \\
\text { throughput. This product is defined using necessity-based logic, } \\
\text { prior to project execution. Project throughput is zero until } \\
\text { completion. Therefore, projects are urgent and duration is their core } \\
\text { measure. }\end{array}$ \\
\hline $\begin{array}{l}\text { Identify the system's } \\
\text { constraint(s) }\end{array}$ & $\begin{array}{l}\text { Project comprises a unidirectional sequence of events or tasks with } \\
\text { no loops, where the longest chain defines its duration. }\end{array}$ \\
\hline $\begin{array}{l}\text { Decide how to } \\
\text { exploit the system's } \\
\text { constraint(s) }\end{array}$ & $\begin{array}{l}\text { The only way to reduce duration is to shorten the critical chain by } \\
\text { fast tracking, shared padding and eliminating schedule conflicts of } \\
\text { resources and the schedule is the primary coordination mechanism. }\end{array}$ \\
\hline $\begin{array}{l}\text { Subordinate } \\
\text { everything to the } \\
\text { above decision }\end{array}$ & $\begin{array}{l}\text { A project is executed by a non-dedicated team of multiple } \\
\text { specialised resources and variability needs to be managed using } \\
\text { buffer management to coordinate members leaving and returning to } \\
\text { the project. }\end{array}$ \\
\hline
\end{tabular}


This section concludes by presenting these five characteristics to be considered when applying CCPM: unity of purpose, fixed throughput, urgency, sequential workflow and a non-dedicated team.

\section{Conclusions}

This research responds to a call for undertaking assumption-challenging research and rethinking existing concepts in project management. We have integrated CCPM's explicit and implicit assumptions with the aim of better understanding CCPM, its core advantages and its assumptions about project environments.

The recorded successful applications of CCPM represent a diverse range of projects. Analysis of CCPM literature indicates that CCPM was created in response to prevailing problems observed while using existing scheduling methods: CPM and PERT. These methods overlooked human behaviour and the dynamic nature of execution processes, which led to various dilemmas during execution. With its roots in TOC, CCPM attempts to improve project performance by exploiting the project constraint - defined in CCPM as the longest chain of dependent activities taking into account both task dependencies and resources. Further analysis of the CCPM literature revealed that CCPM perceives a project as a means of delivering a fixed predefined value as fast as possible. Using necessity-based logic, CCPM formulates scope as the minimum viable solution and attempts to prevent scope creep. CCPM's commonly used metaphor, the relay runner, assumes a specific allocation of tasks to resources and a sequential process. CCPM engineers a system to influence human behaviour, while its execution process, buffer management, coordinates people using both the $\mathrm{CC}$ schedule and mutual adjustment. We identified five characteristics that projects need to have, or be adapted to have, in order for CCPM to fully apply and provide the expected benefits. These characteristics are: unity of purpose, fixed throughput, urgency, sequential workflow and a non-dedicated team.

Further analyses also revealed that effective application of CCPM requires appropriate measurement systems. This is because the way in which performance is defined and measured directly affects all decisions in a system. This answers the second question raised regarding use of the CCPM scheduling method in isolation from its underpinning philosophy. It is argued here that the definitions of a project's goal and its value put the rest of the measures of a project into perspective. CCPM presents itself as a device that brings focus to project environments, not just in the planning process but throughout execution. The emphasis on scheduling is based on perceived urgency in the project environment as well as viewing the schedule as the primary coordination mechanism; however, to treat CCPM merely as a scheduling method, divorced from its basic philosophy, is unlikely to yield the full benefits.

\subsection{Implications for practice}

With these assumptions explicitly stated, project management practitioners can assess whether their project meets these assumptions before deciding whether or not to use CCPM. They can also examine what aspects of CCPM should be altered to accommodate their specific requirements, or vice versa; what type of changes they need to make to their project in order to gain core benefits of CCPM. This includes discussions around 
accommodating iteration and reciprocal dependencies and dealing with uncertainty, how resources are allocated and managed, how the project scope is defined and so on. In addition, practitioners can use these propositions to examine the ways in which CCPM can be improved to better suit their projects and to devise alternative solutions that take advantage of CCPM's underpinning concepts, in this way managing projects according to each project's core constraint.

Likewise, in a multi-project environment the application of TOC to project environments is not entirely different from the application of TOC to any other environment. The core constraints may not be prejudged to be a resource, or an integration point or the number of projects being worked on. Instead, the core constraints are identified by a thorough analysis of the system, its goal and how it functions.

\subsection{Implications for research}

In this paper, the assumptions of CCPM were made explicit after in-depth analysis of the CCPM literature. This research contributes to CCPM by defining clear boundaries and providing the logical reasons for these boundaries. The notion of project characteristics and their potential impact on definition of core constraints, serves as a base for future studies on constraint classification for projects. TOC thinking-process tools can enhance future research in identifying core constraints. Future research can also validate these assumptions using empirical data. Another area for future research would be to identify how CCPM practitioners adapt CCPM or accommodate these assumptions in the context of their projects. In particular, more case study reporting is required to provide rich description that can highlight the relevance of current theoretical debates to practice.

This study suggests answering the question of applicability of a project management method by examining what assumptions were made when proposing the method. The process identifies and extracts the often-implicit assumptions of CCPM as an example of an already-existing method and reconstructs its underpinning model. By comparing this model with actual projects (whether or not they used the particular method), we can gain insight into the logic that connects characteristics of actual projects to the functions of a particular method. These propositions can also provide insights into the existing and future research that seeks to compare and contrast project management methods for particular types of projects.

\section{References}

Abouzahra, M.M. (2011) 'Building the e-learning system in King Saud University, a system perspective', Proceedings of the World Congress on Engineering and Computer Science, Vol. 2, pp.247-253, Newswood Limited, San Francisco, CA.

Ahlemann, F., El Arbi, F., Kaiser, M.G. and Heck, A. (2012) 'A process framework for theoretically grounded prescriptive research in the project management field', International Journal of Project Management, Vol. 31, pp.43-56, DOI: 10.1016/j.ijproman.2012.03.008.

Ashtiani, B., Jalali, G.R., Aryanezhad, M.B. and Makui, A. (2007) 'A new approach for buffer sizing in critical chain scheduling', Paper presented at the 2007 IEEE International Conference on Industrial Engineering and Engineering Management, Singapore, December.

Bacharach, G. and Techi, U. (2013) 'Introducing multi-project management using TOC standards', TOCICO International Conference: 11th Annual Worldwide Gathering of TOC Professionals, Frankfurt, Germany, June. 
Bevilacqua, M., Ciarapica, F.E. and Giacchetta, G. (2009) 'Critical chain and risk analysis applied to high-risk industry maintenance: a case study', International Journal of Project Management, Vol. 27, No. 4, pp.419-432, DOI: 10.1016/j.ijproman.2008.06.006.

Biesenthal, C. and Wilden, R. (2014) 'Multi-level project governance: trends and opportunities', International Journal of Project Management, Vol. 32, No. 8, pp.1291-1308.

Blackstone, J.H., Gardiner, L.R. and Gardiner, S.C. (1997) 'A framework for the systemic control of organizations', International Journal of Production Research, Vol. 35, No. 3, pp.597-609.

Budd, C.S. (2010) 'Traditional measures in finance and accounting, problems, literature review, and TOC measures', in Cox, J.F. and Schleier, J.G. (Eds.): Theory of Constraints Handbook, pp.335-372, McGraw-Hill, New York, NY.

Chang, S.H., Kan, C.P. and Wang, M.L. (2010) 'TOC portfolio selection model for NPD projects of the biotechnological industry', Proceedings of IEEE 17th International Conference on Industrial Engineering and Engineering Management (IEEM), pp.170-174.

Cohen, I., Mandelbaum, A. and Shtub, A. (2004) 'Multi-project scheduling and control: a process-based comparative study of the critical chain methodology and some alternatives', Project Management Journal, Vol. 35, No. 2, pp.39-50.

Coman, A. and Ronen, B. (2010) 'Icarus' predicament: managing the pathologies of overspecification and overdesign', International Journal of Project Management, Vol. 28, No. 3, pp.237-244.

Constraint (n.d.) [online] http://www.merriam-webster.com/dictionary/constraint (accessed 30 May 2017).

Cooper, R.G., Edgett, S.J. and Kleinschmidt, E.J. (2005) 'Portfolio management: fundamental to new product success', The PDMA Handbook of New Product Development, Wiley, Hoboken, NJ.

Cox, J.F. (2016) TOC Books List [online] http://www.tocico.org/?page=toc_books_list (accessed 4 April 2018).

Cox, J.F., Boyd, L., Sullivan, T.T., Reid, R.A. and Cartier, B. (2012) The Theory of Constraints International Certification Organization Dictionary, 2nd ed., McGraw-Hill Publishing, New York.

Dann, S. (2010) 'Redefining social marketing with contemporary commercial marketing definitions', Journal of Business Research, Vol. 63, No. 2, pp.147-153.

Deac, V. and Vrincut, M. (2010) 'The advantages of using critical chain project management in planning construction projects', Metalurgia International, Vol. 15, No. 5, pp.54-58.

Deming, W.E. (1986) Out of the Crisis, Massachusetts Institute of Technology, Center for Advanced Engineering Study, Cambridge, MA.

Feldman, R. and Sanger, J. (2007) The Text Mining Handbook: Advanced Approaches in Analyzing Unstructured Data, Cambridge University Press, UK.

Forrester, J. (1961) Industrial Dynamics, MIT Press, Cambridge, MA.

Ghaffari, M. and Emsley, M.W. (2015) 'Current status and future potential of the research on critical chain project', PM World Journal, Vol. 4, No. 9, pp.1-25 [online] http://pmworldlibrary.net/wp-content/uploads/2015/09/pmwj38-Sep2015-Ghaffari-Emsleyresearch-on-critical-chain-second-edition.pdf (accessed 4 April 2018).

Globerson, S. (2000) 'PMBOK and the critical chain', PM Network, Vol. 14, No. 5, pp.63-67.

Goldratt, E.M. (1988) 'Computerized shop floor scheduling', International Journal of Production Research, Vol. 26, No. 3, pp.443-455.

Goldratt, E.M. (1990) The Haystack Syndrome: Sifting Information Out of the Data Ocean, North River Press, Croton-on-Hudson, NY.

Goldratt, E.M. (1997) Critical Chain, North River Press, Great Barrington, MA.

Goldratt, E.M. (2008a) 'Keynote presentation: what is TOC?', Paper presented at the TOCICO International Conference: 6th Annual Worldwide Gathering of TOC Professionals, Las Vegas, Nevada, 1-4 November. 
Goldratt, E.M. (2008b) The Strategy \& Tactic Tree. Projects. Viable Vision Implementations [online] http://public.wsu.edu/ engrmgmt/holt/em534/SandT-Projects.pdf (accessed 4 April 2018).

Goldratt, E.M. (2009) 'Standing on the shoulders of giants: production concepts versus production applications. The Hitachi tool engineering example', Gestão \& Produção, Vol. 16, No. 3, pp.333-343, doi:10.1590/s0104-530x2009000300002.

Goldratt, E.M. (2010) 'Introduction to TOC - my perspective', in Cox, J.F. and Schleier, J.G. (Eds.): Theory of Constraints Handbook, pp.3-9, McGraw-Hill, New York, NY.

Goldratt, E.M. and Fox, R.E. (1986) The Race, North River Press, Croton-on-Hudson, NY.

Groves, L., Nickson, R., Reeve, G., Reeves, S. and Utting, M. (2000) 'A survey of software development practices in the New Zealand software industry', in Proceedings of the 2000 Australian Software Engineering Conference, Canberra, Australia, IEEE Computer Society Press, Los Alamitos, CA, 28-29 April, pp.189-201.

Gupta, A., Bhardwaj, A. and Kanda, A. (2010) 'Fundamental concepts of theory of constraints: An emerging philosophy', International Journal of Social, Behavioral, Educational, Economic, Business and Industrial Engineering, Vol. 4, No. 10, pp.2089-2095.

Hallgren, M. (2012) 'The construction of research questions in project management', International Journal of Project Management, Vol. 30, No. 7, pp.804-816, DOI: 10.1016/j.ijproman. 2012.01.005.

Hazır, O., Haouari, M. and Erel, E. (2010) 'Robust scheduling and robustness measures for the discrete time/cost trade-off problem', European Journal of Operational Research, Vol. 207, No. 2, pp.633-643.

Heptinstall, I. and Bolton, R. (2016) The Executive Guide to Breakthrough Project Management: Capital \& Construction Projects; On-time in Less Time; On-budget at Lower Cost; Without Compromise, Denehurst Consulting Limited, Norwich, UK.

Herroelen, W. and Leus, R. (2001) 'On the merits and pitfalls of critical chain scheduling', Journal of Operations Management, Vol. 19, No. 5, pp.559-577, DOI: 10.1016/S02726963(01)00054-7.

Herroelen, W. and Leus, R. (2004) 'Robust and reactive project scheduling: a review and classification of procedures', International Journal of Production Research, Vol. 42, No. 8, pp.1599-1620.

Herroelen, W., Leus, R. and Demeulemeester, E. (2002) 'Critical chain project scheduling: do not oversimplify', Project Management Journal, Vol. 33, No. 4, pp.46-60.

Hofstede, G. (1978) 'The poverty of management control philosophy', The Academy of Management Review, Vol. 3, No. 3, pp.450-461, DOI: 10.2307/257536.

Hopp, W.J. and Spearman, M.L. (1996) Factory Physics, McGraw Hill, Boston.

Horman, M.J. and Thomas, H.R. (2005) 'Role of inventory buffers in construction labor performance', Journal of Construction Engineering and Management, Vol. 131, No. 7, pp.834-843.

Huang, C.L., Chen, H.C., Li, R.K. and Tsai, C.H. (2012) 'A comparative study of the critical chain and PERT planning methods: no bad human behaviors involved', International Journal of Academic Research in Business and Social Sciences, Vol. 2, No. 8, pp.379-394.

Huang, C.L., Li, R.K., Chung, Y.C., Hsu, Y.W. and Tsai, C.H. (2013) 'A study of using critical chain project management method for multi-project management improvement', International Journal of Academic Research in Economics and Management Sciences, Vol. 2, No. 3, pp.55-67.

Huang, X.B. and Yang, L.X. (2009) 'Setting lead-time in project manufacturing environment based on CCPM', in Proceedings of the International Conference on Apperceiving Computing and Intelligence Analysis, ICACIA, Chengdu, China, pp.407-410. 
Ishibashi, K., Hashimoto, M., Katamine, K., Shiratsuchi, R., Asaine, K., Nakatani, T. and Akiyama, Y. (2008) 'A discussion on domain modeling in an example of motivation-based human resource management', in Proceedings of the 8th Joint Conference on Knowledge-Based Software Engineering, pp.32-41.

Jian Bing, L., Hong, R. and Ji Hai, X. (2008) 'critical chain project management-based heuristic algorithm for multiple resources-constrained projects', in International Seminar on Business and Information Management, IEEE, Wuhan, China, December, Vol. 1, pp.330-335.

Johnson, S.B. (2001) 'Samuel Phillips and the taming of Apollo', Technology and Culture, Vol. 42, No. 4, pp.685-709.

Kania, E., Housden, G. and Hitchner, K. (2002) 'The theory of constraints: a unique alternative to traditional project management', Drug Information Journal, Vol. 36, No. 3, pp.611-621.

Kendall, G.I. (2010) 'Theory of constraints strategy', in Cox, J.F. and Schleier, J.G. (Eds.): Theory of Constraints Handbook, pp.519-550, McGraw-Hill, New York, NY.

Kendall, G.I. and Austin, K.M. (2012) Advanced Multi-project Management: Achieving Outstanding Speed and Results with Predictability, J. Ross, Ft. Lauderdale, FL.

Kishira, Y. (2006) 'A case study of reengineering public works management at a Japanese government ministry through a 'P2M\#' based program and project management method', $P M$ World Today, Vol. 8, No. 11, pp.1-8.

Koskela, L.J. and Howell, G. (2002a) 'The theory of project management: explanation to novel methods', Paper presented at the 10th Annual Conference on Lean Construction, IGLC-10, Gramado, Brazil, August.

Koskela, L.J. and Howell, G. (2002b) 'The underlying theory of project management is obsolete', in Proceedings of the PMI Research Conference, PMI, DC, pp.293-302.

Koskela, L.J., Stratton, R. and Koskenvesa, A. (2010) 'Last planner and critical chain in construction management: comparative analysis', in Proceedings of the 18th Annual Conference of the International Group for Lean Construction, IGLC, Haifa, Israel, pp.538-547.

Kuo, T.C., Chang, S.H. and Huang, S.N. (2009) 'Due-date performance improvement using TOC's aggregated time buffer method at a wafer fabrication factory', Expert Systems with Applications, Part 1, Vol. 36, No. 2, pp.1783-1792, DOI: 10.1016/j.eswa.2007.12.038.

Leach, L.P. (1999) 'Critical chain project management improves project performance', Project Management Journal, Vol. 30, No. 2, pp.39-51.

Leach, L.P. (2000) Critical Chain Project Management, Artech House, Boston, MA.

Leach, L.P. (2003) 'Schedule and cost buffer sizing: how to account for the bias between project performance and your model', Project Management Journal, Vol. 34, No. 2, pp.34-47.

Leach, L.P. (2005) Lean Project Management: Eight Principles for Success, Advanced Projects, Inc., Boise, ID.

Lechler, T.G., Ronen, B. and Stohr, E.A. (2005) 'Critical chain: a new project management paradigm or old wine in new bottles?', Engineering Management Journal, Vol. 17, No. 4, pp.45-58.

Leus, R. (2004) 'The generation of stable project plans', Quarterly Journal of the Belgian, French and Italian Operations Research Societies, Vol. 2, No. 3, pp.251-254.

Leximancer (2010) Leximancer Manual Version 3.5 [online] https://leximancer.com/gallery/ (accessed 10 February 2014).

Liesch, P.W., Håkanson, L., McGaughey, S.L., Middleton, S. and Cretchley, J. (2011) 'The evolution of the international business field: a scientometric investigation of articles published in its premier journal', Scientometrics, Vol. 88, No. 1, pp.17-42.

Luong, L. and Ario, O. (2007) 'Solving the resource-constrained project scheduling problem by genetic algorithm', Journal of Japan Industrial Management Association, Vol. 57, No. 6, pp.520-529. 
Luong, L.D. and Ohsato, A. (2008) 'Fuzzy critical chain method for project scheduling under resource constraints and uncertainty', International Journal of Project Management, Vol. 26, No. 6, pp.688-698.

Martin, N.J. and Rice, J.L. (2007) 'Profiling enterprise risks in large computer companies using the Leximancer software tool', Risk Management, Vol. 9, No. 3, pp.188-206.

McKay, K.N. and Morton, T.E. (1998) 'Review of the book Critical Chain', Transactions, Vol. 30, No. 8, pp.759-762, DOI: 10.1080/07408179808966521.

Millhiser, W.P. and Szmerekovsky, J.G. (2012) 'Teaching critical chain project management: the academic debate and illustrative examples', INFORMS Transactions on Education (ITE), Vol. 12, No. 2, pp.67-77.

Min, Y. and Shou-rong, L. (2013) 'Influence of behavioral factors on project schedule management: a Monte Carlo method', in 25th Chinese Control and Decision Conference (CCDC), Industrial Electronics (IE), Singapore, May, pp.4831-4835.

Mirzaei, M. (2016) Exploring Applicability of Theory of Constraints to Projects: Critical Chain Project Management and Beyond, unpublished Doctoral thesis, Victoria University of Wellington, Wellington, New Zealand.

Mirzaei, M. and Mabin, V.J. (2015) 'Variability in project scheduling and the impact of team type', Proceedings of the Joint NZSA+ORSNZ Conference, Christchurch, New Zealand.

Mirzaei, M., Mabin, V.J. and Sheffield, J. (2014) 'Using theories to predict contextual applicability of a method: the case of critical chain project management', Poster presented at the PMI Research and Education Conference. Portland, OR.

Morris, P.W.G. (2013) Reconstructing Project Management, John Wiley and Sons, Cambridge, MA.

Newbold, R.C. (1998) Project Management in the Fast Lane: Applying the Theory of Constraints, St. Lucie Press, Boca Raton, FL.

Newbold, R.C. (2008) The Billion Dollar Solution: Secrets of Prochain Project Management, ProChain Solutions, Inc., Lake Ridge, VA.

Newbold, R.C. and Lynch, B. (2014) The Project Manifesto: Transforming Your Life and Work with Critical Chain Values, ProChain Solutions, Inc., Lake Ridge, VA.

Packendorff, J. (1995) 'Inquiring into the temporary organization: new directions for project management research', Scandinavian Journal of Management, Vol. 11, No. 4, pp.319-333, DOI: 10.1016/0956- 5221(95)00018-Q.

Parr, J.A. (2000) 'Habitat speedbuild using critical chain - a house in under four hours. Prosperity through partnership', World Project Management Week. Incorporating Project Management Global Conf., CD-Rom, Australian Institute of Project Management, Sydney

Paseuth, S. (2003) An Analysis of Critical Chain Project Management Application, Masters thesis, Victoria University of Wellington, New Zealand [online] http://helicon.vuw.ac.nz/ login?url=http:/restrictedarchive.vuw.ac.nz/handle/123456789/4217

Pittman, P.H. (1994) Project Management: A More Effective Methodology for the Planning and Control of Projects, unpublished Doctoral dissertation, University of Georgia at Athens, Georgia, USA.

Platje, A., Seidel, H. and Wadman, S. (1994) 'Project and portfolio planning cycle: project-based management for the multiproject challenge', International Journal of Project Management, Vol. 12, No. 2, pp.100-106.

PMI (2015) Pulse of the Profession: Capturing the Value of Project Management through Knowledge Transfer, Project Management Institute, Newtown Square, PA.

Pollack, J. (2007) 'The changing paradigms of project management', International Journal of Project Management, Vol. 25, No. 3, pp.266-274, DOI: 10.1016/j.ijproman.2006.08.002.

Rahman, M.M. and Kumaraswamy, M.M. (2004) 'Contracting relationship trends and transitions', Journal of Management in Engineering, Vol. 20, No. 4, pp.147-161. 
Rand, G.K. (2000) 'Critical chain: the theory of constraints applied to project management', International Journal of Project Management, Vol. 18, No. 3, pp.173-177, DOI: 10.1016/ S0263-7863(99)00019-8.

Raz, T., Barnes, R. and Dvir, D. (2003) 'A critical look at critical chain project management', Project Management Journal, Vol. 34, No. 4, pp.24-32.

Realization Technologies (2010) 'Getting durable results with critical chain: a field report', in Cox, J.F. and Schleier, J.G. (Eds.): Theory of Constraints Handbook, pp.79-100, McGraw-Hill, New York, NY.

Reddy, G. (2009) 'Testing processes in business-critical chain software lifecycle', in Software Engineering, 2009. WCSE'09, IEEE, WRI World Congress on Software Engineering, May, Vol. 4, pp.238-242.

Ronen, B., Lechler, T.G. and Stohr, E.A. (2012) 'The 25/25 rule: achieving more by doing less', International Journal of Production Research, Vol. 50, No. 24, pp.7126-7133.

Schmenner, R.W. and Swink, M.L. (1998) 'On theory in operations management', Journal of Operations Management, Vol. 17, No. 1, pp.97-113.

Scott, N. and Smith, A.E. (2005) 'Use of automated content analysis techniques for event image assessment', Tourism Recreation Research, Vol. 30, No. 2, pp.87-91.

Sculli, D. and Wong, K.L. (1985) 'The maximum and sum of two beta variables and the analysis of PERT networks', Omega, Vol. 13, No. 3, pp.233-240.

Seashore, S.E. and Yuchtman, E. (1967) 'Factorial analysis of organizational performance', Administrative Science Quarterly, Vol. 12, No. 3, pp.377-395.

Senge, P.M. (2006) The Fifth Discipline, 2nd ed., Doubleday/Currency, New York, NY.

Smith, A.E. and Humphreys, M.S. (2006) 'Evaluation of unsupervised semantic mapping of natural language with Leximancer concept mapping', Behavior Research Methods, Vol. 38, No. 2, pp.262-279.

Smith, D.G. (2012) Theory of Constraints Project Management: Improving Cost, Schedule, Performance, and Overall Effectiveness, Doctoral dissertation [online] http://gradworks.umi. com/35/15/3515678.html.

Srinivasan, M.M., Best, W.D. and Chandrasekaran, S. (2007) 'Warner Robins Air Logistics Center streamlines aircraft repair and overhaul', Interfaces, Vol. 37, No. 1, pp.7-21, DOI: 10.1287/ inte. 1060.0260 .

Steyn, H. (2001) 'An investigation into the fundamentals of critical chain project scheduling', International Journal of Project Management, Vol. 19, No. 6, pp.363-369, DOI: 10.1016/ S0263-7863(00)00026-0.

Steyn, H. (2002) 'Project management applications of the theory of constraints beyond critical chain scheduling', International Journal of Project Management, Vol. 20, No. 1, pp.75-80, DOI: 10.1016/S0263-7863(00)00054-5.

Stretton, A. (2007) 'A short history of modern project management', PM World Today, Vol. 9, No. 10 , pp.1-18.

Thompson, J.D. (1967) Organizations in Action; Social Science Bases of Administrative Theory, McGraw-Hill, New York, NY.

TOCICO (2011) The Six Steps to Standing on the Shoulders of Giants [online] http://www.tocico. org/news/news.asp?id=70878.

Turner, J.R. and Muller, R. (2003) 'On the nature of the project as a temporary organization', International Journal of Project Management, Vol. 21, No. 1, pp.1-8, DOI: 10.1016/S02637863(02)00020-0.

Umble, M. and Umble, E.J. (2000) 'Manage your projects for success: an application of the theory of constraints', Production and Inventory Management Journal, Vol. 41, No. 2, pp.27-32.

Van de Vonder, S., Demeulemeester, E., Herroelen, W. and Leus, R. (2005) 'The use of buffers in project management: the trade-off between stability and make span', International Journal of Production Economics, Vol. 97, No. 2, pp.227-240. 
Viljoen, P.J. and Steyn, H. (2007) 'A conceptual model for improved project selection and prioritisation', Journal of Industrial Engineering and Engineering Management, Vol. 18, No. 1, pp.91-106.

Walker, E.D. (1998) Planning and Controlling Multiple, Simultaneous, Independent Projects in a Resource Constrained Environment, unpublished Doctoral dissertation, University of Georgia, Athens, Georgia, USA.

Walker, E.D. (2010) 'The problems with project management', in Cox, J.F. and Schleier, J.G. (Eds.): Theory of Constraints Handbook, pp.13-44, McGraw-Hill, New York, NY.

Winter, M., Smith, C., Morris, P. and Cicmil, S. (2006) 'Directions for future research in project management: the main findings of a UK government-funded research network', International Journal of Project Management, Vol. 24, No. 8, pp.638-649, DOI: 10.1016/ j.ijproman.2006.08.009.

Yang, J.B. (2007) 'How the critical chain scheduling method is working for construction projects', Cost Engineering, Vol. 49, No. 4, pp.25-33.

Yeo, K.T. and Ning, J.H. (2002) 'Integrating supply chain and critical chain concepts in engineer-procure-construct (EPC) projects', International Journal of Project Management, Vol. 20, No. 4, pp.253-262, DOI: 10.1016/s0263-7863(01)00021-7.

Yeo, K.T. and Ning, J.H. (2006) 'Managing uncertainty in major equipment procurement in engineering projects', European Journal of Operational Research, Vol. 171, No. 1, pp.123-134, DOI: 10.1016/j.ejor.2004.06.036.

Yu, H.H. and Chiu, S.K. (2007) 'A feasible case study of applying critical chain multi-project management in semiconductor turnkey services', Proceedings of ICM 2007; The 6th International Conference on Management, Wuhan, China.

Zwikael, O., Cohen, Y. and Sadeh, A. (2006) 'Non-delay scheduling as a managerial approach for managing projects', International Journal of Project Management, Vol. 24, No. 4, pp.330-336, DOI: 10.1016/j.ijproman.2005.11.002. 